\title{
Efisiensi Makan Spodoptera exigua (Lepidoptera: Noctuidae) pada Bawang Daun, Sawi Hijau dan Seledri di Laboratorium
}

\author{
Nova Hariani ${ }^{1)}$, Intan Ahmad ${ }^{2 *}$ dan Resti Rahayu ${ }^{3)}$ \\ ${ }^{1)}$ Program Studi Biologi, Fakultas Matematika dan Ilmu Pengetahuan Alam, Universitas Mulawarman, Kalimantan Timur 75123 \\ ${ }^{2}$ Sekolah Ilmu Teknologi Hayati, Institut Teknologi Bandung, Bandung 40132 \\ 3) Jurusan Biologi, Fakultas Matematika dan Ilmu Pengetahuan Alam, Universitas Andalas, Padang 25163
}

Diterima 23-11-2010Ｄisetujui 04-04-2011

\begin{abstract}
The aim of this research is to gain further understanding of how particular insect species respons to different host plants. This research is considered as preliminary research in integrated pest management for Spodoptera exigua. We report herein the consumption and utilization of green onion (Allium fistulosum), caisin (Brassica rapa subsp. Parachinensis) and celery (Apium graveolens) by Spodoptera exigua. The evaluation of indices of food consumption, growth and food utilization showed that caisin (Brassica rapa subsp. Parachinensis) was the best food for the last instar larvae of $S$. exigua as compared with celery or green onion. Growth rates and efficiency of conversion of ingested food to biomass (ECI) were significantly higher for larvae fed caisin $(11.93 \%)$ than for those given green onion $(8.06 \%)$ or celery $(7.74 \%)$ Although the protein content of caisin $(2.23 \%)$ was a bit lower than that of green onion $(2.45 \%)$ but higher than celery (1.28\%), we suspect that the larvae performed best in caisin due to good balance between protein and carbohydrate as well as water content in caisin as compared with other host plants.
\end{abstract}

Keywords: caisin, celery, green onion, nutrition indices, Spodoptera exigua

\section{PENDAHULUAN}

Banyak larva serangga fitofagus yang hidup dalam lingkungan makanan dengan kandungan nutrisi yang heterogen. Serangga ini harus bisa beradaptasi terhadap variasi jumlah dan proporsi nutrisi dalam makanannya (misalnya protein, karbohidrat, dan berbagai elemen lainnya) yang secara langsung dapat mempengaruhi pertumbuhan maupun reproduksinya (Tabashnik \& Slanksy 1987). Dengan demikian, karena pertumbuhan dan perkembangan adalah hal yang amat penting bagi semua hewan termasuk serangga, serangga dapat memberikan respons terhadap variasi tersebut dengan dua cara. Pertama dengan melakukan seleksi makan (misalnya menyeimbangkan asupan dengan cara memilih diantara makanan yang tersedia (Ahmad et al. 1993; Ahmad et al. 2001). Kedua, dengan menyesuaikan jumlah makanan yang dimakan (Scriber \& Slansky 1981). Secara alamiah nitrogen bagi serangga fitofagus merupakan faktor pembatas, sedangkan jaringan tumbuhan lebih sedikit mengandung nitrogen jika dibandingkan dengan jaringan hewan (McNeill \& Southwood 1978). Makanan serangga fitofagus biasanya mempunyai kandungan nitrogen dan air yang tinggi yang dibutuhkan untuk mempercepat pertumbuhannya. Kadar nitrogen dan air dalam daun dapat berfluktuasi karena berhubungan dengan musim dan fenologi tumbuhan, keadaan ini dapat mempengaruhi kehidupan (performance) serangga ini (Ahmad \& Kamal 2001).

Dengan demikian, adalah hal yang amat penting bagi serangga fitofagus untuk dapat memperoleh protein secara adekuat dan seimbang dari makanannya. Selanjutnya, bila nutrisi sudah tersedia, yang perlu diketahui adalah bagaimana efisiensi penggunaan nutrisi oleh serangga. Untuk menjawab ini, perlu diketahui berapa bagian dari total makanan yang dimakan yang digunakan untuk pertumbuhan dan akhirnya untuk reproduksi. Pengukuran ini dapat digunakan dengan mempergunakan metoda gravimetri yang dikembangkan oleh Waldbauer (1968).

Lima parameter indeks nutrisi yang umum dipakai dan dapat menggambarkan kinerja serangga yang dibuat Waldbauer (1968), dan telah dimodifikasi oleh Scriber dan Slansky (1981), adalah: laju konsumsi (Consumption Ratel CR), laju pertumbuhan (Growth Rate/GR), perkiraan jumlah pakan yang dicerna (Approximate Digestibility/AD), efisiensi konversi makanan yang dicerna (Efficiency of Conversion of Digested food/ ECD), efisiensi konversi makanan yang dimakan (Efficiency of Conversion of Ingested food/ECI). Efisiensi penggunaan makanan yang tinggi dapat dilihat sebagai indikator kualitas nutrisi dari suatu makanan yang dapat berupa suatu tanaman, bagian dari tanaman atau makanan buatan. Banyak penelitian yang sudah dilakukan, 
antara lain yang dilaporkan oleh Scriber dan Slansky (1981), yang membandingkan dan menganalisis berbagai efisiensi penggunaan makanan berbagai serangga pada berbagai tanaman inang. Demikian pula penelitian yang pernah dilakukan dalam kondisi laboratorium menunjukkan bahwa pada Bombyx mori, parameter efisiensi penggunaan makanan dapat dipergunakan untuk melihat makanan yang terbaik bagi B. mori (Ahmad et al. 1995).

Ulat grayak Spodoptera exigua bersifat kosmopolitan dan polifagus. Larva serangga ini mempunyai inang lebih kurang 90 sampai 200 spesies tumbuhan dari 18 famili (Greenberg et al. 2001). Di Indonesia S. exigua merupakan salah satu hama terpenting yang banyak menyerang tanaman palawija dan sayuran dengan tingkat kerusakan yang tinggi. Bahkan pada pertanaman bawang merah, kerugian dapat mencapai 100\% (Negara 2003).

S.exigua adalah hama polifagus yang amat merugikan dan banyak menyerang berbagai jenis tanaman. Tambahan pengetahuan tentang bagaimana serangga ini berinteraksi dengan berbagai tanaman inang akan dapat membantu kita mengembangkan strategi pengendalian $S$. exigua yang lebih baik. Alasan lain mengapa dilakukan penelitian ini terhadap S. exigua, karena beberapa penelitian terdahulu dengan Spodoptera exempta menunjukan bahwa serangga ini mempunyai kemampuan untuk melakukan seleksi makan (Ahmad et al. 2001). Kemampuan dari S. exempta memilih makanan bukan berdasarkan rasa tetapi berdasarkan kandungan nutrisinya (Ahmad \& Kamal 2001). Dengan demikian serangga ini mempunyai kemampuan untuk menyesuaikan baik jumlah maupun jenis makanannya agar dapat tumbuh dan berkembang secara optimal. Ahmad et al. (2001), telah melaporkan bahwa pertumbuhan serangga akan tetap optimal walaupun membatasi sumber makanannya pada makanan buatan yang hanya terdiri dari protein dan karbohidrat sebagai sumber nutrisi.

Penelitian ini untuk mengetahui respon ulat grayak Spodoptera exigua pada berbagai jenis tanaman, dimana ulat ini dikenal sebagai hama, yaitu bawang daun/Allium fistulosum (Amaryllidaceae), sawi hijau/Brassica rapa (Brassicaceae) dan seledri/Apium graveolens (Umbelliferae), respon ini dilihat dengan parameter nilai indeks nutrisi (Kalshoven 1981). Variabel-variabel yang menggambarkan konsumsi makan, berapa banyak makanan yang dikonversikan menjadi biomassa serangga, dan laju pertumbuhan dapat mengarahkan pada pemahaman mengenai bagaimana spesies serangga tertentu memberikan respons kesesuaian terhadap tanaman inang yang bervariasi
(Waldbauer 1968; Scriber \& Slansky 1981; Greenberg et al. 2001).

Dengan demikian hasil penelitian ini diharapkan dapat memberikan kontribusi kepada pemahaman mendasar kita terhadap bagaimana serangga berinteraksi dengan tanaman, dan mengevaluasui kerusakan yang ditimbulkannya. Kedua hal ini dapat digunakan untuk merancang strategi pengendalian hama (Spodoptera exigua) yang efektif.

\section{BAHANDANMETODA}

Hewan Uji. Spodoptera exigua dikoleksi dari pertanaman bawang daun di Ciwidey (Pertanaman bawang daun terluas di Jawa Barat) dipelihara di laboratorium untuk mengetahui siklus hidupnya serta larva uji yang akan digunakan dalam percobaan nantinya. Pemeliharaan serangga uji ini dilakukan hingga turunan kedua dengan makanan yang berbeda yaitu bawang daun, sawi hijau dan seledri. Larva serangga uji yang digunakan pada semua percobaan adalah larva instar V (newly moulted) dan belum diberi makan. Selama pemeliharaan dan perlakuan temperatur ruangan $22-28^{\circ} \mathrm{C}$, kelembaban relatif udara $52-95 \%$ dan foto periodisitas 12:12. Metoda untuk memelihara larva dan dewasa mengacu kepada metoda yang dijelaskan oleh Patana (1985).

Pengukuran Konsumsi Makan. Parameter pertumbuhan dan konsumsi makan serta efisiensi makan larva diukur berdasarkan metoda gravimetri Waldbauer (1968). Untuk berat kering larva dan pakan, didapatkan dengan menggunakan aliquot untuk masing-masing kelompok larva dan pakan. Sehingga untuk perlakuan selanjutnya berat kering masing-masing larva dan pakan sudah bisa ditentukan. Berat kering larva dan pakan diperoleh dengan mengeringkan dalam oven $60^{\circ} \mathrm{C}$ selama 6 hari.

Daun yang tidak dimakan larva dan feses yang dihasilkan larva dikumpulkan setiap hari dan dikeringkan dalam oven sampai beratnya konstan. Jumlah pakan yang dimakan larva dihitung dengan mengurangi jumlah pakan yang diberikan dengan sisa pakan.

Waktu selama perioda instar V larva dicatat, akhir dari perioda instar $\mathrm{V}$ ini ditandai dengan berhenti makan dan larva dipelihara sampai mejadi pupa. Pupa ini dibunuh dan dkeringkan sehingga diperoleh berat akhir.

Pertumbuhan dan efisiensi makan larva. Tiga kelompok larva instar IV Spodoptera exigua yang sudah berhenti makan dipisahkan dan diamati sampai terjadi moulting menjadi instar V. Segera setelah ganti kulit 
masing-masing larva ditimbang beratnya. Larva diberi pakan yang sudah diketahui beratnya, setiap hari pakan diganti dengan yang baru, sisa pakan serta feses masing-masing larva dikumpulkan dan dikeringkan.

Perhitungan indeks nutrisi dari Waldbauer. Indeks nutrisi Waldbauer (1968), yang telah dimodifikasi Scriber \& Slansky (1981), digunakan dalam penelitian ini adalah:

1. Laju Pertumbuhan Larva (GR)

2. Laju Konsumsi Larva (CR)

3. Efisiensi dari konversi pakan yang dicerna (ECD)

4. Efisiensi dari konversi pakan yang dimakan larva (ECI)

5. Perkiraan pakan yang dicerna (AD)

Semua perhitungan menggunakan berat kering.

Pengukuran kadar protein total dan karbohidrat masing-masing pakan. Pengukuran protein total dan karbohidrat bawang daun, sawi hijau dan seledri menggunakan metoda Kjeldahl (Halonen et al. 1983).

Analisa data. Untuk melihat perbedaan dari masingmasing nilai indeks nutrisi yang diukur, maka dilakukan analisa dengan analisa sidik ragam (ANOVA). Jika terdapat perbedaan dilanjutkan dengan uji Duncan (Zar 1996).

\section{HASIL DAN PEMBAHASAN}

Pertambahan berat (mg), perioda makan (jam), jumlah pakan yang dimakan (mg), laju pertumbuhan (GR: mg/hari) dan laju konsumsi makan (CR: mg/hari) larva instar V Spodoptera exigua pada 3 jenis pakan dapat dilihat pada Tabel 1. Secara umum terlihat bahwa walaupun kelompok larva diberi pakan yang berbeda tapi masih bisa menunjang pertumbuhan dan perkembangannya.

Dari nilai rata-rata pertambahan berat, perioda makan instar V, jumlah pakan yang dimakan, laju pertumbuhan dan laju konsumsi makan (CR) terlihat bahwa walaupun laju konsumsi dan jumlah pakan yang dimakan tidak berbeda dengan larva yang diberi pakan bawang daun, tetapi larva yang diberi sawi hijau mempunyai pertambahan berat dan laju pertumbuhan (GR) yang paling tinggi dibandingkan dengan kelompok larva yang diberi pakan bawang daun dan seledri (Tabel 1).
Nilai AD atau nilai yang mengestimasi efisiensi keseluruhan dari nutrien yang dicerna dan diserap dari dalam makanan ke dalam usus, tidak menunjukkan ada perbedaan diantara ketiga jenis pakan yang diberikan (Tabel 2). Demikian pula dengan nilai ECD yang merupakan efisiensi konversi makanan yang dicerna ke biomasa, tampak tidak ada perbedaan. Hal ini sebenarnya agak diluar dugaan karena laju pertumbuhan tertinggi (GR) yang diperoleh pada larva yang memakan sawi hijau berbeda dengan GR dari larva yang memakan bawang daun dan seledri. Kelompok larva yang memakan sawi hijau harus makan lebih banyak dan mungkin membutuhkan lebih banyak juga energi, yang berakibat kepada nilai ECD yang tidak berbeda satu sama lain. Tetapi bila melihat nilai ECI, yaitu penggunaan makanan secara keseluruhan, tampak bahwa sawi hijau dapat memberikan nilai ECI yang tertinggi yaitu 11,93\% jika dibandingkan dengan bawang daun $(8,06 \%)$ dan seledri $(7,74 \%)$. Nilai ECI yang lebih tinggi jika dibandingkan dengan bawang daun dan seledri mengindikaskian bahwa sawi hijau adalah makanan yang terbaik bagi $S$. exigua. Kandungan protein yang ada dalam sawi hijau sebesar 2,23\% (Tabel 3), walau nampak lebih rendah dari bawang daun $(2,45 \%)$ tetapi sawi hijau mempunyai kandungan karbohidrat yang lebih tinggi yaitu $4,10 \%$, Kendati karbohidrat ini mungkin saja tidak begitu penting secara nutrisi, tetapi keberadaannya dalam jumlah tertentu mampu membuat pertumbuhan menjadi optimal (Ahmad et al. 2001).

Tabel 2 Nilai Perkiraan Pakan yang Dicerna (AD), Efisiensi dari Konversi Makanan yang Dicerna (ECD) dan Efisiensi dari Konversi Makanan yang dimakan (ECI) dari larva Instar V Spodoptera exigua pada 3 jenis pakan

\begin{tabular}{|c|c|c|c|}
\hline Jenis pakan & Nilai AD (\%) & Nilai ECD (\%) & Nilai ECI \\
\hline Bawang Da & $47,49 \pm 13,22^{a}$ & $20,19 \pm 12,97^{a}$ & $8,06 \pm 3,96^{\mathrm{a}}$ \\
\hline Sawi & $49,87 \pm 11,27^{\mathrm{a}}$ & $24,82 \pm 9,98^{a}$ & $11,93 \pm 4,65^{b}$ \\
\hline Seledri & $42,86 \pm 14,66^{\mathrm{a}}$ & $21,10 \pm 16,91^{\mathrm{a}}$ & $7,74 \pm 5,37^{\mathrm{a}}$ \\
\hline
\end{tabular}

Tabel 3 Kadar Protein, Karbohidrat dan Air dari 3 Jenis Pakan (bawang daun, sawi hijau, seledri)

\begin{tabular}{lccc}
\hline Jenis Pakan & $\begin{array}{c}\text { Kadar Protein } \\
(\%)\end{array}$ & $\begin{array}{c}\text { Kadar Karbohidrat } \\
(\%)\end{array}$ & $\begin{array}{c}\text { Kadar Air } \\
(\%)\end{array}$ \\
\hline Bawang Daun & 2,45 & 1,98 & 91,36 \\
Sawi hijau & 2,23 & 4,10 & 94,03 \\
Seledri & 1,28 & 1,83 & 88,56 \\
\hline
\end{tabular}

Tabel 1 Pertambahan berat, perioda makan, jumlah pakan yang dimakan, laju pertumbuhan (GR) dan laju konsumsi makan (CR) larva instar V Spodoptera exigua pada 3 jenis pakan

\begin{tabular}{lccrr}
\hline \multicolumn{1}{c}{ Jenis Pakan } & $\begin{array}{c}\text { Pertambahan berat } \\
(\mathrm{mg})\end{array}$ & $\begin{array}{c}\text { Perioda makan } \\
\text { instar V (jam) }\end{array}$ & $\begin{array}{c}\text { Jumlah yang dimakan } \\
(\mathrm{mg})\end{array}$ & GR (mg/hari) \\
\hline Bawang daun & $37,48 \pm 7,14^{\mathrm{a}}$ & $101,28 \pm 10,32^{\mathrm{a}}$ & $498,12 \pm 174,75^{\mathrm{b}}$ & $8,89 \pm 2,25^{\mathrm{a}}$ \\
Sawi hijau & $70,77 \pm 33,68^{\mathrm{b}}$ & $99,12 \pm 12,24^{\mathrm{b}}$ & $599,14 \pm 233,01^{\mathrm{b}}$ & $109,30 \pm 36,50^{\mathrm{ab}}$ \\
Seledri & $23,82 \pm 14,28^{\mathrm{a}}$ & $109,44 \pm 8,16^{\mathrm{a}}$ & $333,93 \pm 122,23^{\mathrm{a}}$ & $15,52 \pm 7,66^{\mathrm{b}}$ \\
\hline
\end{tabular}

Nilai rata-rata dalam satu kolom yang diikuti huruf yang sama tidak berbeda secara statistik dengan analisa ANOVA diikuti uji lanjut

Duncan, $\mathrm{p}<0,05$

$\mathrm{N}=20$ untuk tiap perlakuan 
Selain itu, kandungan air yang lebih tinggi pada sawi hijau $(94,03 \%)$ diperkirakan turut membantu lebih banyak makanan yang diasimilasi seiring dengan bertambahnya asupan makanan (Waldbauer 1968).

Bahwa parameter penggunaan efisiensi makanan dapat digunakan untuk melihat kualitas makanan inang pernah juga dilaporkan oleh Ahmad et al. (1995). Hasil penelitian mereka menunjukkan bahwa pendekatan dengan metoda indeks nutrisi dapat digunakan untuk menentukan jenis murbei yang terbaik bagi pertumbuhan Bombyx mori. Hasilnya menunjukkan bahwa Morus nigra adalah jenis murbei yang paling baik bagi ulat sutera dibandingkan dengan Morus multicaulis, Morus alba atau Morus cathayana. Indeks nutrisi juga dapat digunakan untuk melihat pengaruh metabolit sekunder pada tanaman inang terhadap tingkat pertumbuhan serangga, seperti yang dilaporkan oleh Colom et al. (2007). Mereka melaporkan bahwa asetogenin secara nyata dapat mengurangi laju pertumbuhan dan efisiensi pertumbuhan (ECI) Spodoptera frugiperda.

Bila dilihat kandungan protein sawi hijau, yaitu 2,23\%, walau nampak lebih rendah dari bawang daun $(2,45 \%)$ tetapi sawi hijau mempunyai kandungan karbohidrat yang lebih tinggi yaitu 4,10\%, dibandingkan dengan bawang daun $(1,98 \%)$ dan seledri $(1,83 \%)$. Kendati karbohidrat ini mungkin saja tidak begitu penting secara nutrisi, tetapi keberadaannya dalam jumlah tertentu mampu membuat pertumbuhan menjadi optimal (Ahmad et al. 2001). Selain itu kandungan air yang lebih tinggi pada sawi hijau (94,03\%) diperkirakan turut membantu lebih banyak makanan yang diasimilasi seiring dengan bertambahnya asupan makanan (Waldbauer 1968).

\section{SIMPULAN}

Berdasarkan kepada parameter indeks nutrisi laju pertumbuhan (GR), efisiensi makanan yang dimakan (ECI), serta kombinasi kandungan protein dan karbohidrat dalam daun, sawi hijau adalah makanan yang terbaik bagi S. exigua jika dibandingkan dengan bawang daun dan seledri. Tingginya laju pertumbuhan (GR) pada sawi hijau akan berakibat terhadap kelulushidupan dan potensi reproduksi. Dengan demikian pengetahuan dan pemahaman ini akan dapat membantu kita merancang program pengendalian hama yang lebih baik dengan konsep pegendalian hama terpadu.

\section{UCAPANTERIMAKASIH}

Terimakasih kepada Ketua Laboratorium Entomologi SITH ITB, yang sudah memberikan izin dan fasilitas laboratorium untuk pelaksanaan penelitian ini.

\section{DAFTAR PUSTAKA}

Ahmad, I., Waldbauer, G.P. \& Friedman, S. 1993. Maxillectomy Does not Disrupt Self-Selection by Larvae Manduca sexta (Lepidoptera: Sphingidae). Ann. Entomol. Soc. Am 86(4): 458463 .

Ahmad, I. Lubis, A. \& Sastrodihardjo, S. 1995. Food utilization parameters could be used to indicate food suitability in the silkworm, Bombyx mori. J. Biosains 1(1): 5-7.

Ahmad, I. \& Kamal, M. 2001. Consumption and Utilization of Complete Defined Diets Containing Various Carbohydrate by Spodoptera exempta (Lepidoptera; Noctuidae). BIOTA VI(3): 99-104.

Ahmad, I., Hariyadi, S. \& Anggaraeni, T. 2001. Nutrient Self Selection by the Armyworm, Spodoptera exempta WALKER (Lepidoptera: Noctuidae) Larvae. Pakistan Journal of Biological Sciences 4(6): 684-687.

Colom, O.A., Neske, A., Popich, S. \& Bardón, A. 2007. Toxic Effect of Annonaceous Acetogenins from Annona cherimolia (Magnoliales: Annonaceae) on Spodoptera frugiperda (Lepidoptera: Noctuidae). J. Pest Sci. 80: 63-67.

Greenberg, S.M., Sappington, T.W., Legaspi, B.C.Jr., Liu, T.X. \& Sétamou. 2001. Feeding and Life History of Spodoptera exigua (Lepidoptera: Noctuidae) on Different Host Plants. Ann. Entomol. Soc. Am 94(4): 566-575.

Halonen, O., Tulkki, H. \& Derome, J. 1983. Nutrient analysis methods. Research Paper 121. Finnish Forest Research Institute, $28 \mathrm{pp}$.

Kalshoven, L.G.E. 1981. Pest of Crops in Indonesia. PT. Ichtiar Baru van Hoeve, Jakarta. p.345.

McNeill, S. \& Southwood, T.R.E. 1978. The role of nitrogen in the development of insect/plant relationship. In: J.B. Harborne (ed.). Biochemical Aspect of Plant and Animal Coevolution. Pp. 77-98. London: Academic Press.

Negara, A. 2003. Penggunaan analisis probit untuk pendugaan tingkat kepekaan populasi Spodoptera exigua terhadap deltametrin di Daerah Istimewa Yogyakarta. Informatika Pertanian 12: 1-9

Patana, R. 1985. Spodoptera exigua., In: Hanbook of Insect Rearing Vol. II (eds) P. Singh \& R.F. Moore. pp: 465-468. Elsevier Amsterdam-oxford-New York-Tokyo.

Scriber, J.M. \& Slansky, F.Jr. 1981. The Nutritional Ecology of Immature Insect. Ann. Rev. Entomol 26: 183-211.

Tabashnik, B.E. \& Slansky, F.Jr. 1987. Nutritional ecology of forb foliage-chewing insects.. In: F. Slansky, Jr., and J.G. Rodriguez (eds). Nutritional Ecology of Insects, Mites, Spiders and Related Invertebrates. Pp. 71-103. John Wiley \& Sons, New York.

Waldbauer, G.P. 1968. The Consumption and Utilization of Food by Insect. Advan. Insect Physiol 5: 229-288.

Zar, J.H. 1996. Biostatistical analysis. $3^{\text {th }}$ ed. Prentice-Hall, Englewood Cliffs, NJ. 
